\title{
Prevalensi dan frekuensi gen buta warna siswa sekolah dasar di Kabupaten Badung, Bali, Indonesia
}

\author{
Prevalence and gene frequency of colour blindness among students of elementary schools \\ in Badung Regency, Bali, Indonesia \\ Ni Wayan Karolina, Made Pharmawati*, Iriani Setyawati \\ Program Studi Biologi, Fakultas Matematika dan Ilmu Pengetahuan Alam, Universitas Udayana, \\ Kampus Bukit Jimbaran, Badung, Bali \\ *Email: made_pharmawati@unud.ac.id
}

Diterima 30 Juni 2018; Disetujui 22 Juli 2019

\section{INTISARI}

Buta warna merupakan penyakit keturunan yang terpaut kromosom-X. Buta warna terdiri atas tiga tipe yaitu monokromat (buta warna total), dikromat (buta warna parsial), dan anomali trikromat. Sebagian besar cacat buta warna tidak terdeteksi, sehingga perlu dilakukan identifikasi sejak dini. Tujuan dari penelitian ini adalah untuk mengetahui prevalensi dan frekuensi gen buta warna pada populasi siswa SD di Kabupaten Badung. Kabupaten Badung merupakan salah satu kabupaten di Bali yang terdiri atas enam kecamatan yaitu Kecamatan Petang, Kecamatan Abiansemal, Kecamatan Mengwi, Kecamatan Kuta Utara, Kecamatan Kuta, dan Kecamatan Kuta Selatan. Penelitian dilakukan di 11 Sekolah Dasar di tiga kecamatan (Petang, Abiansemal, dan Kuta Utara) dengan total probandus 900 orang. Pengujian cacat buta warna dilakukan dengan uji Ishihara plate test, kemudian data dianalisis dengan SPSS versi 22. Frekuensi gen dikalkulasi dengan metode Hardy-Weinberg equilibrium. Prevalensi buta warna pada siswa SD di Kabupaten Badung yaitu $2 \%$ dari 900 probandus. Frekuensi gen buta warna pada laki-laki yaitu 0,0378 dan pada perempuan yaitu 0,0022. Perbedaan jenis kelamin pada frekuensi buta warna didapatkan signifikan secara statistik $(\mathrm{P}<$ 0,0001 ), dengan prevalensi pada laki-laki 3,78\% lebih tinggi dibandingkan perempuan $0,22 \%$.

Kata kunci: buta warna, frekuensi gen, Ishihara Test, prevalensi

\begin{abstract}
Colour blindness is a hereditary disease that linked to $\mathrm{X}$ chromosome. There are three types of colour blindness, those are monochromat (total colour blindness), dichromat (partial colour blindness), and anomaly trichromat. The study aimed to determine the prevalence and gene frequencies of colour blindness among students of elementary schools in Badung regency, Bali. Badung is one of regency in Bali which consists of six districts i.e. Petang, Abiansemal, Mengwi, North Kuta, Kuta, and South Kuta. The study was conducted in 11 elementary schools in three districts (Petang, Abiansemal, and Nort Kuta) with total number of students tested were 900 students. The colour blindness was determined using Ishihara plate test, and data were analyzed with SPSS ver. 22. The gene frequency was calculated using Hardy-Weinberg equilibrium method. The prevalence of colour blindness on students of elementary schools at Badung regency is $2 \%$ from 900 respondents. The gene frequencies were 0,0378 among males and 0,0022 among females. The gender based on difference in the frequency of colour blind was found to be statistically significant $(\mathrm{P}<$ 0,0001 ), with a higher prevalence among males $3,78 \%$ as compared to females $0,22 \%$.
\end{abstract}

Keywords: Colour blindness, Ishihara test, gene frequency 


\section{PENDAHULUAN}

Buta warna disebut juga Colour Vision Deficiency (CVD) merupakan ketidakmampuan mata dalam membedakan warna tertentu yang disebabkan oleh gen resesif c kromosom X (Suryo, 2013). Gangguan penglihatan buta warna dapat bersifat kongenital (bawaan sejak lahir) atau akuisital (dapatan setelah lahir). Frekuensi buta warna bervariasi antar populasi, umumnya terjadi pada laki-laki sebesar $8 \%$ dan perempuan sebesar 0,4\% (Fareed et al., 2015).

Penglihatan warna dipengaruhi oleh tiga tipe sel kerucut (merah, hijau, dan biru) yang berbeda panjang gelombangnya. Individu dengan penglihatan normal merupakan trikromatik yaitu memiliki ketiga tipe sel kerucut pada retina yang secara maksimal sensitif terhadap cahaya dengan panjang gelombang 420, 530, dan $560 \mathrm{~nm}$ (short, medium, dan long wavelength; disingkat S, M, L) (Deeb dan Motulsky, 2011). Jika salah satu tipe sel kerucut atau lebih tidak berfungsi atau kekurangan salah satu fotopigmen akan menyebabkan gangguan penglihatan yaitu buta warna (Wangko, 2013).

Hartono (1990) menyebutkan gen yang menyandikan pigmen biru terletak pada kromosom no 7 , sedangkan gen merah dan hijau terletak pada lengan panjang kromosom X (Xq28). Seorang ibu yang karier (pembawa sifat) pada abnormal gen memiliki kemungkinan $50 \%$ anak laki-laki buta warna. Seorang ayah buta warna hanya menurunkan kromosom X-nya pada anak perempuan, yang mana menurunkan anak perempuan karier dan anak lakilaki normal.

Buta warna secara umum dibedakan menjadi tiga yaitu monokromat (buta warna total), dikromat (buta warna parsial) dan anomali trikomat (kerusakan mekanisme sensitivitas sel kerucut) (Kurnia, 2009). Buta warna 'merah hijau' terdiri atas protan dan deutan. Kelainan protan terjadi karena tidak berfungsinya atau rusaknya mekanisme sensitivitas sel kerucut L, sedangkan deutan tidak berfungsinya atau rusaknya mekanisme sensitivitas sel kerucut M. Deuteranopia atau protanopia terjadi karena tidak berfungsinya sel kerucut hijau atau merah, sedangkan rusaknya mekanisme sensitivitas sel kerucut hijau menyebabkan deuteranomali dan sel kerucut merah pada protanomali (Rulaningtyas et al., 2015).

Perhitungan prevalensi dan frekuensi gen buta warna di antara populasi memiliki beberapa manfaat dalam pekerjaan dan aktivitas sehari-hari yang bersangkutan dengan ketepatan warna. Beberapa pekerjaan seperti telekomunikasi, montir listrik, pelaut, pengemudi kereta, pemandu lalu lintas, pelukis dan pekerjaan lain yang sehari-harinya bekerja dengan mempertimbangkan pengenalan warna (Moudgil et al., 2016). Penelitian ini dapat dilakukan di berbagai wilayah Indonesia yang belum diteliti, salah satunya yaitu di Kabupaten Badung. Tujuan dari penelitian ini adalah untuk mengetahui prevalensi dan frekuensi gen buta warna pada populasi siswa Sekolah Dasar di Kabupaten Badung.

\section{MATERI DAN METODE}

\section{Pengambilan sampel}

Kabupaten Badung terletak pada $8^{\circ} 14^{\prime} 17^{\prime \prime}$ -

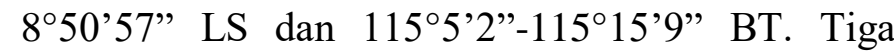
kecamatan yaitu Petang, Abiansemal, dan Kuta Utara dipilih secara acak. Masing-masing kecamatan dipilih secara acak tiga sampai empat Sekolah Dasar (SD). Setiap kecamatan yang dipilih, diambil anak laki-laki maupun perempuan yaitu 150 laki-laki dan 150 perempuan umur 8-12 tahun yang diasumsikan sudah bisa membaca. Pengambilan data pada anak Sekolah Dasar (SD) dilakukan di 11 Sekolah Dasar di tiga kecamatan di Kabupaten Badung dari bulan Desember 2017 sampai Februari 2018. Informasi juga diperoleh dengan memerikasa kembali (cross check) orang tua probandus. Total 900 probandus anak diambil dari 11 SD yaitu SDN 1 Kerobokan $(n=100)$, SDN 4 Kerobokan $(n=100)$, SDN 3 Kerobokan $(n=100)$, SDN 4 Sibang Kaja (n=89), SDN 2 Dauh Yeh Cani $(n=62)$, SDN 3 Darmasaba ( $n=100)$, SDN 2 Taman $(n=49)$, SDN 2 Carangsari $(n=100)$, SDN 1 Petang $(n=100), \quad$ SDN 2 Sulangai $(n=25), \quad$ SDN 3 Carangsari $(\mathrm{n}=75)$.

Semua probandus yang dipilih merupakan peserta yang tidak dalam kondisi sakit (sehat). Probandus selanjutnya diuji dengan Ishihara Plate Test (Ishihara, 1972). Data yang dikumpulkan 
meliputi nama, jenis kelamin, umur, dan silsilah parental. Tes buta warna dilakukan dengan jarak 75 $\mathrm{cm}$ dari probandus, dan skrining dilakukan di luar ruangan yang terpapar sinar matahari. Pengujian dilakukan dengan membaca Ishihara Plate Test yaitu plate 1 hingga plate 38 . Probandus diberi kesempatan membaca tiap plate selama 5-7 detik. Hasil tes buta warna ditulis pada lembar jawaban oleh probandus yang dibantu oleh pencatat. Jika probandus dapat membaca total 17 plate atau lebih dari total plate maka probandus dikategorikan memiliki penglihatan normal. Jika hanya 13 plate atau kurang yang dibaca normal, maka penglihatan dianggap defisiensi. Berdasarkan Ishihara (1972), jika probandus dapat membaca angka 5, 2, 45, dan 73 pada plate 18, 19, 20, dan 21 lebih mudah daripada saat membaca angka pada plate 14, 10, 13, dan 17 maka dikategorikan abnormal. Plate 22, 23, 24, dan 25 digunakan untuk membedakan tipe buta warna protan dan deutan. Tahap selanjutnya yaitu dilakukan wawancara dengan probandus dengan sifat buta warna atau wawancara dilakukan dengan orang tua probandus.

\section{Analisis statistik}

Analisis statistik menggunakan SPPS versi 22. Chi-square test (x2) digunakan untuk menentukan perbedaan yang signifikan (Fareed et al., 2015).

$$
x^{2}=\Sigma \frac{\text { (observed number }- \text { expected number })^{2}}{\text { expected number }}
$$

\section{Analisis frekuensi gen}

Diandaikan alel $\mathrm{C}=\mathrm{p}$, dan alel $\mathrm{c}=\mathrm{q}$, maka frekuensi gen buta warna dihitung dengan metode Hardy-Weinberg $(\mathrm{p} 2+\mathrm{q} 2+2 \mathrm{pq}=1)$ (Fareed et al., 2015). Frekuensi alel gen untuk laki-laki, perempuan, digabungkan dikombinasikan dengan cara:

\section{Untuk laki-laki}

$$
c=\frac{96 \text { color blind phenotype }}{100}
$$

Jadi $\mathrm{C}=1-\mathrm{c}$
2. Untuk perempuan

$$
\begin{aligned}
& c=\sqrt{\frac{96 \text { color blind phenotype }}{100}} \\
& \text { Jadi } \mathrm{C}=1-\mathrm{c}
\end{aligned}
$$

3. Untuk kelompok kombinasi

$$
\left.c=\frac{1}{3} x c(\text { Male })+\frac{2}{3} x c \text { (Female }\right)
$$

Jadi $\mathrm{C}=1-\mathrm{c}$

Homozigositas (Ho) dan Heterozigositas ditentukan dengan rumus (Fareed et al., 2015):

$$
\begin{aligned}
& H_{0}=\sum P i^{2} \\
& \text { ladi, } H_{t}=1-\sum H_{0} \\
& \mathrm{Pi}=\text { frekuensi genotip homozigot }
\end{aligned}
$$

\section{HASIL}

Frekuensi fenotip defisiensi penglihatan warna berdasarkan jenis kelamin pada 11 SD di Kabupaten Badung ditunjukkan pada Tabel 1. Hasil kombinasi buta warna menunjukkan frekuensi tertinggi diantara 11 SD di Kabupaten Badung yaitu pada SDN 2 Dauh Yeh Cani $(4,84 \%)$ dari 62 probandus dan frekuensi terendah yaitu pada SDN 2 Taman ${ }^{2}$ (49 probandus) dan SDN 2 Carangsari (100 probandus) yaitu (0\%). Perbedaan diantara populasi secara statistik tidak signifikan $(\chi 2=8,178 ; \mathrm{df}=10$; $\mathrm{P}=0,611)$. Frekuensi Colour Vision Deficiency (CVD) kombinasi mengikuti tren yaitu SDN 2 Dauh Yeh Cani $(4,84 \%)>\operatorname{SDN} 2$ Sulangai $(4,00 \%) \geq$ SDN 3 Carangsari $(4,00 \%)>$ SDN 4 Sibangkaja $(2,25 \%)>$ SDN 1 Kerobokan $(2,00 \%) \geq$ SDN 4 Kerobokan $(2,00 \%) \geq$ SDN 3 Kerobokan Kaja $(2,00 \%) \geq$ SDN 3 Darmasaba $(2,00 \%)>$ SDN 1 Petang $(1,00 \%)>$ SDN 2 Taman $(0 \%) \geq$ SDN 2 Carangsari $(0 \%)$. Namun, perbedaan berdasarkan jenis kelamin untuk CVD menunjukkan nilai yang signifikan $(\chi 2=14,512 ; \mathrm{df}=1 ; \mathrm{P}<0,0001)$. Pada 900 probandus, frekuensi CVD ditemukan lebih tinggi sebanyak $17(3,78 \%)$ pada laki-laki daripada perempuan sebanyak $1(0,22 \%)$. 
Tabel 1. Frekuensi fenotip buta warna pada siswa laki-laki dan perempuan dari 11 SD di tiga kecamatan di Kabupaten Badung.

\begin{tabular}{|c|c|c|c|c|c|c|c|}
\hline \multirow{3}{*}{ Populasi } & \multirow{3}{*}{$\mathbf{N}$} & \multicolumn{6}{|c|}{ Frekuensi Fenotip } \\
\hline & & \multicolumn{2}{|c|}{ Laki-laki } & \multicolumn{2}{|c|}{ Perempuan } & \multicolumn{2}{|c|}{ Kombinasi } \\
\hline & & Normal & CVD & Normal & CVD & Normal & CVD \\
\hline SDN 1 Kerobokan & 100 & $48(96,00 \%)$ & $2(4,00 \%)$ & $50(100,00 \%)$ & $0(0,00 \%)$ & $98(98,00 \%)$ & $2(2,00 \%)$ \\
\hline SDN 4 Kerobokan & 100 & $48(96,00 \%)$ & $2(4,00 \%)$ & $50(100,00 \%)$ & $0(0,00 \%)$ & $98(98,00 \%)$ & $2(2,00 \%)$ \\
\hline SDN 3 Kerobokan Kaja & 100 & $48(96,00 \%)$ & $2(4,00 \%)$ & $50(100,00 \%)$ & $0(0,00 \%)$ & $98(98,00 \%)$ & $2(2,00 \%)$ \\
\hline SDN 4 Sibang Kaja & 89 & $48(96,00 \%)$ & $2(4,00 \%)$ & $39(100,00 \%)$ & $0(0,00 \%)$ & $87(97,75 \%)$ & $2(2,25 \%)$ \\
\hline SDN 2 Dauh Yeh Cani & 62 & $31(93,94 \%)$ & $2(6,04 \%)$ & $28(96,55 \%)$ & $1(3,45 \%)$ & $59(95,16 \%)$ & $3(4,84 \%)$ \\
\hline SDN 3 Darmasaba & 100 & $48(96,00 \%)$ & $2(4,00 \%)$ & $50(100,00 \%)$ & $0(0,00 \%)$ & $98(98,00 \%)$ & $2(2,00 \%)$ \\
\hline SDN 2 Taman & 49 & $17(100,00 \%)$ & $0(0,00 \%)$ & $32(100,00 \%)$ & $0(0,00 \%)$ & $49(100,00 \%)$ & $0(0,00 \%)$ \\
\hline SDN 2 Carangsari & 100 & $50(100,00 \%)$ & $0(0,00 \%)$ & $50(100,00 \%)$ & $0(0,00 \%)$ & $100(100,00 \%)$ & $0(0,00 \%)$ \\
\hline SDN 1 Petang & 100 & $49(98,00 \%)$ & $1(2,00 \%)$ & $50(100,00 \%)$ & $0(0,00 \%)$ & $99(99,00 \%)$ & $1(1,00 \%)$ \\
\hline SDN 2 Sulangai & 25 & $10(90,91 \%)$ & $1(9,09 \%)$ & $14(100,00 \%)$ & $0(0,00 \%)$ & $24(96,00 \%)$ & $1(4,00 \%)$ \\
\hline SDN 3 Carangsari & 75 & $36(92,31 \%)$ & $3(7,69 \%)$ & $36(100,00 \%)$ & $0(0,00 \%)$ & $72(96,00 \%)$ & $3(4,00 \%)$ \\
\hline Total & 900 & $433(96,22 \%)$ & $17(3,78 \%)$ & $449(99,78 \%)$ & $1(0,22 \%)$ & $882(98,00 \%)$ & $18(2,00 \%$ \\
\hline
\end{tabular}

Ket. Hasil yang disajikan: $\mathrm{n}=$ jumlah sampel; CVD = Color Vision Deficient buta warna. Kombinasi adalah gabungan laki-laki dan perempuan. Populasi berdasarkan nilai chi-square untuk laki-laki $\left(\chi^{2}=6,071 ; \mathrm{df}=10 ; \mathrm{p}=0,809\right)$, perempuan $\left(\chi^{2}=14,550 ; \mathrm{df}\right.$ $=10 ; \mathrm{p}=0,149)$, dan kombinasi $\left(\chi^{2}=8,178 ; \mathrm{df}=10 ; \mathrm{p}=0,611\right)$ ditemukan tidak signifikan. Nilai chi-square untuk perbedaan berdasarkan jenis kelamin $\left(\chi^{2}=14,512 ; \mathrm{df}=1 ; \mathrm{p}<0,0001\right)$ secara statistik signifikan.

Tabel 2. Prevalensi kelainan akromat, deutan, dan protan pada siswa laki-laki

\begin{tabular}{|c|c|c|c|c|c|c|c|}
\hline \multirow{3}{*}{$\begin{array}{c}\text { Jenis } \\
\text { Kelamin }\end{array}$} & \multirow{3}{*}{ Populasi } & \multirow{3}{*}{$\mathbf{N}$} & \multicolumn{5}{|c|}{ Prevalensi Kelainan } \\
\hline & & & \multirow[b]{2}{*}{ Akromat } & \multicolumn{2}{|c|}{ Protan } & \multicolumn{2}{|c|}{ Deutan } \\
\hline & & & & Prota nopia & $\begin{array}{c}\text { Prota } \\
\text { nomaly }\end{array}$ & $\begin{array}{c}\text { Deutera } \\
\text { nopia }\end{array}$ & $\begin{array}{l}\text { Deutera } \\
\text { Nomaly }\end{array}$ \\
\hline \multirow{11}{*}{ Laki-laki } & SDN 1 Kerobokan & 50 & $0(0,00 \%)$ & $0(0,00 \%)$ & $0(0,00 \%)$ & $0(0,00 \%)$ & $2(4,00 \%)$ \\
\hline & SDN 4 Kerobokan & 50 & $0(0,00 \%)$ & $0(0,00 \%)$ & $0(0,00 \%)$ & $1(2,00 \%)$ & $1(2,00 \%)$ \\
\hline & SDN 3 Kerobokan Kaja & 50 & $0(0,00 \%)$ & $0(0,00 \%)$ & $0(0,00 \%)$ & $2(4,00 \%)$ & $0(0,00 \%)$ \\
\hline & SDN 4 Sibang Kaja & 50 & $0(0,00 \%)$ & $0(0,00 \%)$ & $0(0,00 \%)$ & $0(0,00 \%)$ & $2(4,00 \%)$ \\
\hline & SDN 2 Dauh Yeh Cani & 33 & $0(0,00 \%)$ & $0(0,00 \%)$ & $0(0,00 \%)$ & $0(0,00 \%)$ & $2(6,06 \%)$ \\
\hline & SDN 3 Darmasaba & 50 & $0(0,00 \%)$ & $0(0,00 \%)$ & $0(0,00 \%)$ & $1(2,00 \%)$ & $1(2,00 \%)$ \\
\hline & SDN 2 Taman & 17 & $0(0,00 \%)$ & $0(0,00 \%)$ & $0(0,00 \%)$ & $0(0,00 \%)$ & $0(0,00 \%)$ \\
\hline & SDN 2 Carangsari & 50 & $0(0,00 \%)$ & $0(0,00 \%)$ & $0(0,00 \%)$ & $0(0,00 \%)$ & $0(0,00 \%)$ \\
\hline & SDN 1 Petang & 50 & $0(0,00 \%)$ & $0(0,00 \%)$ & $0(0,00 \%)$ & $1(2,00 \%)$ & $0(0,00 \%)$ \\
\hline & SDN 2 Sulangai & 11 & $0(0,00 \%)$ & $0(0,00 \%)$ & $0(0,00 \%)$ & $1(9,09 \%)$ & $0(0,00 \%)$ \\
\hline & SDN 3 Carangsari & 39 & $0(0,00 \%)$ & $0(0,00 \%)$ & $0(0,00 \%)$ & $2(5,13 \%)$ & $1(2,56 \%)$ \\
\hline & Total & 450 & $0(0,00 \%)$ & $0(0,00 \%)$ & $0(0,00 \%)$ & $8(1,78 \%)$ & $9(2,00 \%)$ \\
\hline
\end{tabular}

Tabel 2 dan Tabel 3 menunjukkan prevalensi kelainan akromat, deutan, dan protan berdasarkan jenis kelamin. Berdasarkan Tabel 2 dan 3 tersebut, frekuensi akromat dan protan untuk laki-laki dan perempuan sebanyak 0\%. Prevalensi cacat deutan lebih tinggi pada laki-laki dibandingkan perempuan. Frekuensi fenotip tertinggi dari deuteranopia ditemukan pada laki-laki di SDN 2 Sulangai (9,09\%) dari 11 probandus laki-laki dan tidak ada satupun perempuan penderita deuteranopia di 11 SD
Kabupaten Badung. Frekuensi fenotip tertinggi dari deuteranomali ditemukan di SDN 2 Dauh Yeh Cani yaitu $6,06 \%$ dari 33 probandus laki-laki dan hanya $3,45 \%$ dari 29 probandus perempuan.

Frekuensi genotip dan heterozigositas buta warna pada 11 SD di Kabupaten Badung dapat dilihat pada Tabel 4. Laki-laki dengan kromosom X tunggal frekuensi genotipnya sama dengan frekuensi alel (alel $\mathrm{C}$ dan alel c). Perempuan dengan dua kromosom $\mathrm{X}$ disajikan dengan tiga jenis 
genotip yaitu homozigot dominan (CC), heterozigot (Cc), dan homozigot resesif (cc). Sepuluh SD di Kabupaten Badung didapatkan 100\% frekuensi genotip CC (yaitu 1,00) dan didapatkan $0,00 \%$ untuk genotip $\mathrm{Cc}$ dan cc. Heterozigositas (Cc) ditemukan paling tinggi pada SDN 2 Dauh Yeh Cani yaitu 30,24\%.

Tabel 3. Prevalensi kelainan akromat, deutan, dan protan pada anak perempuan

\begin{tabular}{|c|c|c|c|c|c|c|c|}
\hline \multirow{3}{*}{$\begin{array}{c}\text { Jenis } \\
\text { Kelamin }\end{array}$} & \multirow{3}{*}{ Populasi } & \multirow{3}{*}{$\mathbf{n}$} & \multicolumn{5}{|c|}{ Prevalensi Kelainan } \\
\hline & & & \multirow[b]{2}{*}{ Akromat } & \multicolumn{2}{|c|}{ Protan } & \multicolumn{2}{|c|}{ Deutan } \\
\hline & & & & $\begin{array}{l}\text { Prota } \\
\text { nopia }\end{array}$ & $\begin{array}{c}\text { Prota } \\
\text { nomaly }\end{array}$ & $\begin{array}{c}\text { Deutera } \\
\text { nopia }\end{array}$ & $\begin{array}{l}\text { Deutera } \\
\text { Nomaly }\end{array}$ \\
\hline \multirow{11}{*}{ Perempuan } & SDN 1 Kerobokan & 50 & $0(0,00 \%)$ & $0(0,00 \%)$ & $0(0,00 \%)$ & $0(0,00 \%)$ & $0(0,00 \%)$ \\
\hline & SDN 4 Kerobokan & 50 & $0(0,00 \%)$ & $0(0,00 \%)$ & $0(0,00 \%)$ & $0(0,00 \%)$ & $0(0,00 \%)$ \\
\hline & SDN 3 Kerobokan Kaja & 50 & $0(0,00 \%)$ & $0(0,00 \%)$ & $0(0,00 \%)$ & $0(0,00 \%)$ & $0(0,00 \%)$ \\
\hline & SDN 4 Sibang Kaja & 39 & $0(0,00 \%)$ & $0(0,00 \%)$ & $0(0,00 \%)$ & $0(0,00 \%)$ & $0(0,00 \%)$ \\
\hline & SDN 2 Dauh Yeh Cani & 29 & $0(0,00 \%)$ & $0(0,00 \%)$ & $0(0,00 \%)$ & $0(0,00 \%)$ & $1(3,45 \%)$ \\
\hline & SDN 3 Darmasaba & 50 & $0(0,00 \%)$ & $0(0,00 \%)$ & $0(0,00 \%)$ & $0(0,00 \%)$ & $0(0,00 \%)$ \\
\hline & SDN 2 Taman & 32 & $0(0,00 \%)$ & $0(0,00 \%)$ & $0(0,00 \%)$ & $0(0,00 \%)$ & $0(0,00 \%)$ \\
\hline & SDN 2 Carangsari & 50 & $0(0,00 \%)$ & $0(0,00 \%)$ & $0(0,00 \%)$ & $0(0,00 \%)$ & $0(0,00 \%)$ \\
\hline & SDN 1 Petang & 50 & $0(0,00 \%)$ & $0(0,00 \%)$ & $0(0,00 \%)$ & $0(0,00 \%)$ & $0(0,00 \%)$ \\
\hline & SDN 2 Sulangai & 14 & $0(0,00 \%)$ & $0(0,00 \%)$ & $0(0,00 \%)$ & $0(0,00 \%)$ & $0(0,00 \%)$ \\
\hline & SDN 3 Carangsari & 36 & $0(0,00 \%)$ & $0(0,00 \%)$ & $0(0,00 \%)$ & $0(0,00 \%)$ & $0(0,00 \%)$ \\
\hline \multicolumn{2}{|r|}{ Total } & 450 & $0(0,00 \%)$ & $0(0,00 \%)$ & $0(0,00 \%)$ & $0(0,00 \%)$ & $1(0,22 \%)$ \\
\hline
\end{tabular}

Tabel 4. Distribusi frekuensi genotip diantara laki-laki dan perempuan

\begin{tabular}{lccccc}
\hline \multirow{2}{*}{\multicolumn{1}{c}{ Populasi }} & \multicolumn{5}{c}{ Frekuensi Genotip } \\
\cline { 2 - 6 } & \multicolumn{2}{c}{ Laki-Laki } & \multicolumn{3}{c}{ Perempuan } \\
\cline { 2 - 6 } & 0,9600 & 0,0400 & 1,0000 & 0,0000 & 0,0000 \\
SDN 1 Kerobokan & 0,9600 & 0,0400 & 1,0000 & 0,0000 & 0,0000 \\
SDN 4 Kerobokan & 0,9600 & 0,0400 & 1,0000 & 0,0000 & 0,0000 \\
SDN 3 Kerobokan Kaja & 0,9600 & 0,0400 & 1,0000 & 0,0000 & 0,0000 \\
SDN 4 Sibang Kaja & 0,9394 & 0,0604 & 0,6631 & 0,3024 & 0,0345 \\
SDN 2 Dauh Yeh Cani & 0,9600 & 0,0400 & 1,0000 & 0,0000 & 0,0000 \\
SDN 3 Darmasaba & 1,0000 & 0,0000 & 1,0000 & 0,0000 & 0,0000 \\
SDN 2 Taman & 1,0000 & 0,0000 & 1,0000 & 0,0000 & 0,0000 \\
SDN 2 Carangsari & 0,9800 & 0,0200 & 1,0000 & 0,0000 & 0,0000 \\
SDN 1 Petang & 0,9091 & 0,0909 & 1,0000 & 0,0000 & 0,0000 \\
SDN 2 Sulangai & 0,9231 & 0,0769 & 1,0000 & 0,0000 & 0,0000 \\
SDN 3 Carangsari & & & & & \\
\hline \multirow{2}{*}{ Total } & $\mathbf{0 , 9 6 2 2}$ & $\mathbf{0 , 0 3 7 8}$ & $\mathbf{0 , 9 0 8 4}$ & $\mathbf{0 , 0 8 9 4}$ & $\mathbf{0 , 0 0 2 2}$ \\
& & & & &
\end{tabular}




\section{PEMBAHASAN}

Probandus diambil dari siswa Sekolah Dasar yang berusia 8-12 tahun di Kabupaten Badung berdasarkan asumsi bahwa pada usia tersebut, siswa SD telah mampu membaca dan mengenal angka sehingga mampu mengikuti tes buta warna (Ishihara Test). Probandus terdiri atas 900 siswa yang diambil dari 11 SD di tiga kecamatan di Kabupaten Badung. Masing-masing kecamatan diambil sebanyak 300 probandus.

Prevalensi buta warna di 11 SD di Kabupaten Badung, yaitu sebesar 18 (2\%) dari 900 probandus. Siswa laki-laki mendominasi buta warna yaitu 17 orang $(3,78 \%)$, sedangkan perempuan satu orang $(0,22 \%)$. Hasil penelitian ini menunjukkan bahwa jumlah frekuensi fenotip buta warna pada laki-laki lebih besar daripada perempuan. Hasil penelitian Gupta et al. (2017) pada anak sekolah menengah pertama di Bhopal Selatan, India juga mendapatkan frekuensi fenotip buta warna yang lebih besar pada laki-laki yaitu $4.2 \%$ dari 401 laki-laki, sedang frekuensi buta warna pada perempuan adalah $0.59 \%$ dari 337 perempuan. Hasil prevalensi buta warna di antara kelompok etnis yang berbeda pada siswa dan mahasiswa yang berusia 7-25 tahun di Kota Erbil, Irak, yaitu pada laki-laki sebanyak $8,47 \%$ dan perempuan sebanyak 1,37\% dari 1856 probandus (Karim dan Saleem, 2013). Penelitian di Manipur, India Utara menyatakan prevalensi buta warna pada umat muslim yaitu laki-laki $8,73 \%$ dan pada perempuan 1,69\% dari 2654 probandus (Shah et al., 2013). Perbedaan persentase frekuensi fenotip pada penelitian yang berbeda-beda dapat disebabkan oleh rentang jumlah probandus yang berbeda-beda. Menurut Moudgil et al. (2016), laki-laki cenderung memiliki frekuensi buta warna yang lebih tinggi yang memperkuat fakta dari sifat X-linked resesif, yaitu kromosom $\mathrm{X}$ tunggal pada laki-laki adalah predominan (lebih banyak) untuk kelainan buta warna, sementara perempuan memiliki dua kromosom $\mathrm{X}$ sehingga dapat memperkecil resiko buta warna.

Penelitian di 11 SD di Kabupaten Badung mendapatkan hasil satu tipe buta warna yaitu deutan yang terdiri atas deuteranomali dan deuteranopia baik pada laki-laki maupun perempuan. Hasil yang didapatkan menunjukkan $1,78 \%$ probandus menderita deuteranomali dan $2 \%$ probandus deuteranopia pada laki-laki, sedangkan pada perempuan $0,22 \%$ probandus deuteranomali dari total 900 probandus. Menurut Rulaningtyas et al. (2015), deuteranomali merupakan gangguan buta warna karena kelainan bentuk pigmen middlewavelength (hijau). Penderita deuteranomali tidak memiliki masalah terhadap kecerahan (Nugroho, 2013). Hasil yang berbeda ditunjukkan oleh penelitian Fareed et al., (2013) pada 1028 probandus anak-anak berusia 6-15 tahun dari 815 keluarga yang mewakili enam populasi masyarakat muslim di India Utara. Penelitian tersebut mendapatkan prevalensi penderita buta warna dengan dua tipe kelainan yaitu protan $(1,94 \%$ protanomali dan $1,28 \%$ protanopia) serta deutan (5,68\% deuteranomali dan $2,27 \%$ deuteranopia.

Penentuan seseorang menderita protan atau deutan dari pengujian plate 22-28. Keakuratan daya penglihatan yang normal ditentukan oleh ketepatan seseorang dalam mendeterminasi warna-warna absolut, hal ini sangat dibutuhkan pada banyak bidang pekerjaan. Sebagai contoh, penderita kelainan deuteranopia dan protanopia tidak dapat membedakan dengan jelas warna penanda lampu lalu lintas. Sementara individu penderita deutan dan protan yang bekerja di bidang telekomunikasi dan menggunakan kabel listrik hanya dapat mengenali kabel berwarna biru dan putih, namun tidak yakin terhadap kabel berwarna merah, oranye, coklat dan hijau (Fareed et al., 2013).

Frekuensi total gen buta warna pada siswa lakilaki pada penelitian ini yaitu 0,0378, dengan frekuensi gen buta warna tertinggi ditemukan di SDN 2 Sulangai (0,0909). Frekuensi total gen buta warna pada anak perempuan yaitu 0,0022 dengan frekuensi gen buta warna tertinggi ditemukan di SDN 2 Dauh Yeh Cani (0,0345). Penelitian ini menunjukkan nilai heterozigositas rendah yaitu 0,3024 . Nilai heterozigositas yang mendekati 0 (nol) menunjukkan nilai heterozigositas rendah (Nei, 1987). Heterozigot berarti memiliki peluang memberikan sifat buta warna kepada keturunan (Jordan dan Mollon, 1993). Nilai heterozigositas yang rendah akan menyumbang sifat buta warna yang rendah pada populasi. Faktor yang 
mempengaruhi nilai heterozigositas adalah perkawinan acak dan peluang inbreeding (Mulliadi dan Arifin, 2010). Frekuensi gen dalam suatu populasi juga dipengaruhi oleh perkawinan acak, mutasi, migrasi, tidak ada seleksi, dan genetic drift (Noor, 2004). Ukuran sampel juga dapat mempengaruhi frekuensi gen, dimana semakin tinggi ukuran sampel maka semakin tinggi tingkat kepekaan pada pengujian dengan metode HardyWeinberg dan Chi-Square Test (Miller, 1997).

Penelitian ini memberikan informasi pola alel dominan dan resesif. Pengujian buta warna sejak dini dapat membantu dalam pemetaan potensi anak. Identifikasi buta warna sejak dini dapat membantu menemukan strategi adaptif, yang memungkinkan untuk menghindari kekecewaan dalam pemilihan karir masa depan anak. Prevalensi dan frekuensi gen buta warna juga diperlukan untuk tujuan konseling genetik untuk meminimalkan resiko pewarisan sifat-sifat resesif atau gangguan perkembangan dan kecacatan pada keturunan mereka melalui konseling prakonsepsi (Fareed et al., 2015).

\section{SIMPULAN}

Prevalensi buta warna siswa SD di Kabupaten Badung yaitu 2\% dari 900 probandus, sedangkan frekuensi gen buta warna pada laki-laki lebih tinggi dari perempuan. Penelitian ini memberikan perbedaan yang signifikan berdasarkan jenis kelamin dan prevalensi buta warna ditemukan lebih tinggi pada anak laki-laki dibandingkan perempuan. Tipe buta warna yang diperoleh yaitu deutan yang terdiri atas deuteranomali dan deuteranopia pada laki-laki, sedangkan pada perempuan deuteranomali.

\section{UCAPAN TERIMA KASIH}

Penulis mengucapkan terima kasih kepada seluruh siswa di 11 SD di Kabupaten Badung yang telah bersedia menjadi probandus dan kepada Kepala Sekolah di 11 SD di Kabupaten Badung atas waktu dan tempat penelitian.

\section{KEPUSTAKAAN}

Deeb, S. S., and A. G. Motulsky. 2011. Red-Green Color Vision Defects. Available at ncbi.nl.nih.gov. Diakses tanggal 7 Oktober 2017.

Fareed, M., M. A. Anwar, and M. Afzal. 2015. Prevalence and Gene Frequency of Color Vision Impairments among Children of Six Populations from North Indian Region. Journal of Genes and Diseases 2: 211-218.

Gupta, S.C., S. P. Saxena, S. Gupta, R. Saxena, S. Sharma. 2017. The prevalence of colour blindness in middle school student of southern Bhopal. International Journal of Medical and Health Research 3(5): 111-113

Hartono. 1990. Penglihatan Warna dan Genetika Buta Warna. Berkala Ilmu Kedokteran 12(3):107-113.

Ishihara, S. 1972. The Series of Plates Designed as Test for Colour-Blindness. Kanehara Shuppan Co. Ltd. Tokyo, Japan

Jordan, G., and J. D. Mollon. 1993. A study of women heterozygous for color deficiencies. Vision Research 33: 1495-1508

Karim, J. K., and M. A. Saleem. 2013. Prevalence of Congenital Red-Green Color Vision defects among Various Ethnic Groups of Students in Erbil City. Jordan Journal of Biological Sciences 6(3): 235-238.

Kurnia, R. 2009. Penentuan Tingkat Buta Warna Berbasis HIS pada Citra Ishihara, (Seminar Nasional) Aplikasi Teknologi Informasi, Yogyakarta 20 Juni 2009.

Mahajan, O. P., and R. S. Googna. 1977. Study of Color Blindness in Schools Children. Indian Journal Physiology and Pharmacology 21(1):59-62.

Miller, M. P. 1997. Tools for Population Genetics Analyses (TFPGA): a Windows Program for the Analysis of Allozyme and Molecular Population Genetic Data. Available at: http://www.marksgeneticsoftware.net/tfpga.htm

Moudgil, T., R. Arora, and K. Kaur. 2016. Prevalence of Color Blindness in Children. Original Research Article 5(2):1252-1258. 
Mulliadi, D., dan J. Arifin. 2010. Pendugaan Keseimbangan Populasi dan Heterozigositas menggunakan Pola Protein Albumin Darah pada Populasi Domba Ekor Tipis (Javanese Thin Tailed) di Daerah Indramayu. Jurnal Ilmu Ternak 10(2): 65-72.

Nei, M. 1987. Molecular Evolutionary Genetics. New York: Columbia University Press. 175208.

Noor, R. R. 2004. Genetika Ternak. Jakarta: Penebar Swadaya.

Nugroho, T. 2013. Buta Warna dan Strabismus (Mata Juling). Yogyakarta: Nuha Medika

Rulaningtyas, R., A. B. Suksmono, T. L. R. Mengko, dan G. A. P. Saptawati. 2015. Segmentasi Citra Berwarna dengan Menggunakan Metode Clustering Berbasis Patch untuk Identifikasi Mycobacterium tuberculosis. Jurnal Biosains 17(1): 1412-1433.

Shah, A., R., Hussain, M. Fareed and M. Afzal. 2013. Prevalence of Red-Green Color Vision Defects among Muslim Males and Females of Manipur, India. Iran Journal of Public Health 42(1):16-24.

Suryo. 2013. Genetika untuk Strata 1. Yogyakarta: Gadjah Mada University Press.

Wangko, S. 2013. Histofisiologi Mata. Jurnal Biomedik 5(3):1-6. 